DOI: https://doi.org/10.24297/jal.v10i0.8453

\title{
Study of The Effects of Frequency on The Compression Process in Old and New Persian Dialogues in The Bybee Phonological Framework
}

\author{
${ }^{*}$ Razieh Kashefi Khishan **Dr. Maryam Iraji \\ *Islamic Azad University of Central Branch, Linguistic Department, Tehran, Iran \\ **Islamic Azad University of Central Branch, Linguistic Department, Tehran, Iran (Head of Department) \\ *kashefi85@yahoo.com **mar.iraji@iauctb.ac.ir
}

\begin{abstract}
The purpose of this research is an analytical analysis of the compression process (including deletion and merging) in old cinematic films compared to new cinematic films in Persian language. The old cinematic films selected for this study include two films, "Kaiser" and "Treasure of the Qaroon," and new cinematic films that examine two films," Life+1 Day "and "Lottery". The theoretical framework has been used in Cognitive Phonology, Bybee (1999). The method of the present study is descriptive-analytical, and data collection is in library method. All the data has been pulled out from the dialouge of films, which been examined the compression process in the old and new films separately. In this research, we first examine the Utterance and discourse of the intended films in detail. At the end of the work, the elements of the Persian language are analyzed. The results indicate that the compression process in Persian language films has been araised, and in cases where more compressions have been done, their frequency has been higher. That is, in " Life+1 Day and "Lottery's film, there are more compression processes than "Kaiser" and Treasure of the Qaroon's film. The fact that the two categories of nouns and verbs are part of the basic entity of a phrase, such that if these categories are frequent then they are compressed or eliminated. On the other hand, the presence of an adjective, adverb, or letter to describe the replacement of noun or verb in the conceptual connection, which is sufficient to represent them, and this will support with Bybee's view point. So the compression, deleting or merging processes in data has shown less frequently.
\end{abstract}

Keywords: Compression, Film, Bybee's Cognitive Phonology, deletion, merging.

\section{1-Introduction}

In all languages of the world, processes known as phonological processes occur in folk speech. In the Persian Language, also, these processes occur extensively. One of these processes is the process of deletion and merging, which are referred to as compression in this project. There is ample evidence to suggest that phonetic change or change processes affect words gradually and at different rates, and one of the determinants of this speed is the frequency of the word use. Bybee's (1999) suggestion to explain this effect is that changing processes occur at the moment and when the word is used. Each instance of a word's usage affects its representation in memory. Since the usage instances are different, the stored representation should include a set of variations. As the words gradually reduced, the comprehensive center of diversity is also gradually shifted.

According to the principles described in Langacker's Cognitive Grammar (Langacker, 1988) or the Bybee's framework of the associative network (Bybee, 1999), expressions or structures are stored in the mental vocabulary, and generalizations are abstracted from these stored units. In this theoretical framework there is no serious separation of words and grammar in the language, but different units with different length and degree of complexity may be stored in form of words with the following characteristics: $(A)$ the degree of strength or durability of the stored units based on the frequency of the text; $(B)$ the connections or relevance of the two phonological and semantic natures are based on the similarity or identity of the lexical items and (C) Schemes with different generic ratings are derived from these representations. 
Bybee's (1995) view points on phonology introduced the psychological validity of the rule-based patterns into a new domain and showed that the stored form of the language was the result of the individual's exposure to language use. His research has led to the emergence of a view that considers language structure as derived from the interaction between language usage (both in its processing and social and communicative aspects) and the essence of language (both phonetic and semantic. So, it challenges the Generative approach that calls language an abstract system. The models that he has presented to examine the effects of frequency type and sample on all levels of the linguistic structure have made achievements in understanding the important features of language and its linguistic patterns and their relation to human "cognition." Bybee's work on the influence of frequency in language has had important achievements for language study that go far beyond its findings in modeling interlanguage and synchronic patterns of language. His research shows that the nature of language is constantly changing and how a language evolves at any given time span depends largely on the frequency of type and sample in the passage of time. The researches that Bybee has done on the effects of frequency on all levels of language structure and others have followed, play a key role in our understanding of language as well as our understanding of other natural systems, and shows how fixed principles function leads to complexity.

Following Bybee's comments, recent studies of vocabulary changes in the discourse have shown that in many cases, high-frequency words leads to sound changes more quickly than low-frequency words. The two effects of token frequency (the frequency of individual items) seem contradictory since one seems to accelerate change while the other seems to promote conservative behavior. I will argue that the reductive effect of frequency is related to the automation of production. And that the conserving effect of high token frequency affects storage and access to linguistic strings. Both of these effects are related to the fact that language is a conventionalized and even ritualistic cultural object. One effect of high token frequency is the reductive effect, which was discussed in the preceding section. Words and phrases that are used more often undergo compression and reduction as part of the move to automate speech: boundaries are obscured, and segments and syllables may disappear into the mass of co-articulated gestures.

The purpose of this research is to examine analytically the process of compression (including deletion and merging) in old movies compared to new movies. The old films selected for this research are "Kaiser" and " Treasure of the Qaroon," and the new ones are "Lottery" and "Life+1 Day" films. The theoretical framework used in this research is Bybee's cognitive phonology. Problems: What has been the process of compression in old Persian films compared to new films? What is the frequency of the compression process between the two genders in Persian language films? Which elements of Persian are more compressed in the discourse of the films in question?

Hypothesis: The compression process in Persian-language films has been on the rise from the old to the new. The frequency of compression in men is higher than in women. And in the discourse of the films concerned, there is more compression in the Persian verbs.

\section{2- Research Background}

There have been few studies on cognitive phonology. Fowler and Housum (1987; Fowler, C. A. \& Housum, J.) found that the second repetition of a word in a single discourse was significantly shorter than the first-word sample. The speaker can show the shorter oral representation of a word if it is already used because it would be easier to access if it had already activated the word in the listener's mind. In addition, Fowler and Housum point out that this reduction can be a signal to the listener that the word used is just like the previous one, not a new and different word. Thereafter, words or phrases that are often repeated in a similar discourse (high-frequency expressions and grammaticalized) are at shortened form more than low-frequency words and phrases.

Yang et al, (2017): The growth of language: Universal Grammar, experience, and principles of computation. The development of language and the advance of speech in the human infant occur rapidly and without the need for explicit and conscious education. The integration of a fundamental operator into the human language system is fundamental to the formation and production of linguistic structures; there is a wide range of structural and evolutionary or developmental evidences related to human development. Although the merging function is 
more related to the formation of syntactic structures, it also integrates the word formation and semantic units and informational units as they occur in the syntax domain. At the phonological level, there is a similar situation, in fact, the main unit in any phonological construction is the syllable that is consisted of the combination of phonemes resulting in the formation of the syllable, i.e., the onset, the syllable vowel, and the coda terminus. The VOWEL is merged with the CODA to form the RIME, which is then merged with the ONSET to form the syllable (Kahn 1976). The structure of the syllable is universal, whereas the choices of ONSET, VOWEL, and CODA are language-specific and therefore need to be learned. For instance, while neither clight nor zwight is an actual word of English, the former is a potential English word as the $\mathrm{cl}(/ \mathrm{kl} /)$ is a valid onset of English whereas zw is not, but is a possible onset in Dutch. However, in the second phase, syllables are merged, and then feet are formed, which is a special language feature.

John Alderete, Paul Tupper(2018): Connectionist approaches to generative phonology. While connectionist models are ubiquitous in psycholinguistic approaches to language processing, they are less well-known as generative models of grammar. This work surveys a body of literature in which connectionist models have been developed to address problems central to generative phonology. The focus is on explaining to the newcomer precisely how these models work, and in particular, how they grapple with locality, gradience, opacity, and learnability in phonology. An understanding of connectionist phonology both gives a deeper understanding of past developments in phonological theory and a glimpse into its future.

ArkadiuszRojczyk,(2019): Quality and duration of unstressed vowels in Polish. Polish is considered to be a language with no phonological vowel reduction in unstressed syllables. If vowel reduction does not have a phonological function, unstressed vowels are expected to be relatively stable in their quality and duration compared to stressed vowels. However, previous reports have suggested that Polish unstressed vowels may indeed undergo some processes of spectral and durational reduction. In this study, 23 speakers of Polish produced all 6 Polish vowels in $/ \mathrm{dV}^{\prime} \mathrm{dVdV} /$ frames using reiterant speech. The results showed that all vowels in unstressed syllables exhibited some changes in formant frequencies relative to vowels in stressed syllables. The greatest magnitude of reduction was observed for central /a/, and back / $/$ / and /u/. Unstressed vowels were also shorter than stressed vowels with a ratio of 1.45 . These results show that, although Polish unstressed vowels are not phonologically reduced, they are not immune to natural reduction processes caused by unstressed positions. Phonological studies of the usage-based, in contrast to the principle-based and generative approach and optimality, have also been the interest area to Iranian scholars. Bijankhan (2009) argues that deletion is one of the common phonological processes in languages in which one or more phone attributes are eliminated in a given position. In some words, phonemes that have no role in semantic differentiation are omitted. Deletion may occur from the beginning, middle, or end of the word. Deletion of the final phonemes is called "apocope," and deletion of the phoneme from the middle of the word is called "pause" (Bagheri, 1999).

According to Cambozia (2006), the process of frequency-mediated deletion is such that in the continuous discourse, usually consonant clusters with a consonant deletion are simplified, and the number of syllables of multiple syllable-words is reduced by deleting a vowel. Deletion is inconsistent with insertion. A phonemic element may be omitted from the "beginning," "middle," or "end" positions of the word.

In their research, Mikaeeli and Farahani (2005) have considered the phonological processing model as a threedimensional concept consist of the phonological awareness variables, phonological working memory, and rapid automatic naming. Safaei Qalati (2013), believes that experience in cognitive phonology affects linguistic representation. The mental representation of language is not limited to phonetic representation, but the various facets of language components are fully represented in mind. In the cognitive approach, phonological alternations are synchronic changes that are pervaded according to the frequency of occurrence of the linguistic expressions between them.

\section{3- Research Method}

In general, the present study, using the analytical and descriptive method on the script of four movies, first, the compressed items consist deletion and merging in the movie context (old and new) based on Bybee's theory 
have been separately extracted and rewritten. The method of data analysis in this study was both qualitative and quantitative. Qualitative data analysis included the survey and study of the deletion and merging (compression) processes in the mentioned films, and qualitative analysis was the drawing of tables and graphs for these processes, which are presented in the quantitative tables and charts following the qualitative analysis. The duration of each movie is 1 . Kaiser 100 minutes, 2. Treasure of the Qaroon 112 minutes, 3. Life+1 Day 110 minutes, 4. Lottery 114 minutes.

\section{4- Discussion}

\section{Old Movies}

The old cinematic films analyzed in this study are "Kaiser" and "Ganj-e Qarun," "Kaiser," the title of an Iranian film made and directed by Massoud Kimiaie in 1969 and produced by Abbas Shabawiz. The movie "Ganj-e Qarun" is made by Siamak Yasemi in 1965.

In order to analyze the research data, the word compression process, which includes the deletion and merging process, on the nouns, adverbs, verbs, adjectives, and letters of the "Kaiser" film in the discourse of characters of both genders (first female) are examined. At the beginning of the examination, the data in this section; based on the discourses presented by the female characters in the film, are extracted in each kind of word grammatical types such as verbs, nouns, adjectives, adverbs, and letters, and for each of these grammatical types, five to ten cases, if any, are cited and phonographed.

\section{Compression of the Male and Female Characters' Discourse in the "Kaiser" Film}

\section{Deletion Process}

\section{Compression in the discourse of Female Characters in "Kaiser" Movie}

\section{Deletion in Nouns:}

\begin{tabular}{|l|l|l|}
\hline Standard Persian & Standard Phonography & Transcription Criterion \\
\hline Fatima & $/ \cdot \hat{a} \cdots \cdots /$ & $\cdots \hat{a} \cdot \cdot$ \\
\hline
\end{tabular}

1- [2azam: fâti junam kojâs fâti junam]

2- [2azam: tâ yeki do daqe dige čâi hâzer mishe]

3- [2azam: $\underline{2 q}$ dâdâš $]$

1- Azam: Where's Fatima? Dear Fatima.

2. Azam: In a couple of more sec, tea will be ready.

3. Azam: Big Bro!

\section{Deletion in Verbs:}

$\begin{array}{ll}1- & \text { [2azam: fâti kojas] } \\ 2-\quad[\text { [azam: kiye] } \\ 3-\quad \text { [2azam: xândâi izinjâst] }\end{array}$


1- Azam: Where's Fatima?

2- Azam: Who is it?

3. Azam: Great-uncle is here.

\section{Deletion in adverbs:}

1- [2azam: xeile xob bâše]

1- $\quad$ Azam: Ok, let's do.

\section{Deletion in Letters:}

1- [mâdar: dâdâš jun javâbe barâdarâšo či bedam]

2- [mâdar: javâbe farmuno či bedam]

3- $\quad$ [parastâr: 2in tu sinaš bud]

1- Mother: Dear Bro! What can I tell her brothers?

2- Mother: What can I say to Farmoon?

3. Nurse: This paper was in her bra.

\section{Deletion in Adjective:}

1. [zane nešaste dar nimkate bimârestân: šâyad xâterxâ bude]

1- Woman Sitting on Hospital Bench: Maybe She had a crush?

Table (4-1) The Usage of Deletion Process in the Female Characters' Discourse in "Kaiser" Film

\begin{tabular}{|l|l|l|}
\hline & Deletion Process & Frequency of use in speech \\
\hline 1 & Deletion in nouns: & 6 \\
\hline 2 & Deletion in verbs: & 8 \\
\hline 3 & Deletion in adjective & 1 \\
\hline 4 & Deletion in adverbs: & 1 \\
\hline 5 & Deletion in letters: & 6 \\
\hline
\end{tabular}

The Compression in the Characters' Discourse of the Film "Kaiser"

\section{The Deletion Process}

\section{Deletion in noun:}

1- [dâi: čâqu ro dase bačam ke bedi]

2- [2ahmad: mige ke qeisar qol dâde bebaratam mašad]

1- Uncle: Give a knife to a kid... 
2- $\quad$ Ahmad: He says that Kaiser has promised to take me to Mashhad.

\section{Deletion in Verbs:}

1- [dai: če xub šod 2az donyâ raf]

2- [2ahmad: gof mixâd bere qom ziyârat]

3- [qeisar: čon dige 2extiyâram dase xodam ni]

1- Uncle: It was a bless for her to die

2- $\quad$ Ahmed: Said, she wants to go to Qom.

3- Kaiser: Because I have no say-so.

\section{Deletion of Adjectives:}

1- [qeisar:xodet miduni ke man xeili xâter xâtam]

2- [rezâ: siyâpuš daštim]

3- [qeisar: xodam pedaš mikonam]

1- Kaiser: You know I have a crush on you.

2- $\quad$ Reza: We had a mourner.

3- Kaiser: I find him myself.

\section{Deletion in Adverbs:}

1- [dâi: ye dafe didam oftâd labe hoz]

2- [qeisar: man bixodi tu ye mozu2i qâti šodam ke 2asan fekrešo nemikardam]

3- [farmun: 2enqad gerye nakon]

1- Uncle: Suddenly, I saw her fall on the pool edge.

2- $\quad$ Kaiser: I became unnecessarily involved in the matter I had no gist at all.

3- Farmoon: Don't cry so much.

\section{Deletion in Letters:}

1- [dâi: queisaro nemiše kâri kard]

2- [qeisar: bem goftan soheilâ ferdos uno mišnâse]

3- [qeisar: xune zendegim 2azam gerefte šod]

1- Uncle: Anything possible to do for Kaiser.

2- Kaiser: I was told Soheila Ferdows knows him. 
3- Kaiser: All my life is taken away.

Table (4-3) The Usage of Deletion Process in the Discourse of the Male Characters of the "Kaiser" Film

\begin{tabular}{|c|c|c|}
\hline & Deletion Process & The Frequency of Usage in Discourse \\
\hline 1 & Deletion of Nouns & 28 \\
\hline 2 & Deletion in Verbs & 22 \\
\hline 3 & Deletion in Adjectives & 6 \\
\hline 4 & Deletion in adverbs & 4 \\
\hline 5 & Deletion in Letters & 17 \\
\hline
\end{tabular}

\section{The Merging Process}

\section{Merging in Nouns:}

1- [farmun: nâ salâmati manam xârzâdatam]

1- $\quad$ Farmoon: For God's sake, I'm your nephew.

\section{Merging in Adverbs:}

1- [qeisar: miduni ke čaie nane hamiše ruberâs]

1- Kaiser: You know, mom's tea always is ready.

Table (4-4) The Usage of Compression Process in the Discourse of the Male Characters of the "Kaiser" Film

\begin{tabular}{|l|l|l|}
\hline & Merging Process & The Frequency of Usage in Discourse \\
\hline 1 & Merging in Nouns & $\mathbf{4}$ \\
\hline 2 & Merging in verbs & $\mathbf{0}$ \\
\hline 3 & Merging in adjectives & $\mathbf{0}$ \\
\hline 4 & Merging in Adverbs & $\mathbf{1}$ \\
\hline 5 & Merging in Letters & $\mathbf{0}$ \\
\hline
\end{tabular}

Table (4-5) The Usage of Compression Process in the Discourse of the Characters of the "Kaiser" Film

\begin{tabular}{|l|l|l|l|}
\hline & Compression & $\begin{array}{l}\text { The Frequency of Usage in } \\
\text { Female discourse }\end{array}$ & $\begin{array}{l}\text { The Frequency of Usage in Male } \\
\text { discourse }\end{array}$ \\
\hline 1 & Deletion & 21 & 67 \\
\hline 2 & Merging & 1 & 5 \\
\hline
\end{tabular}




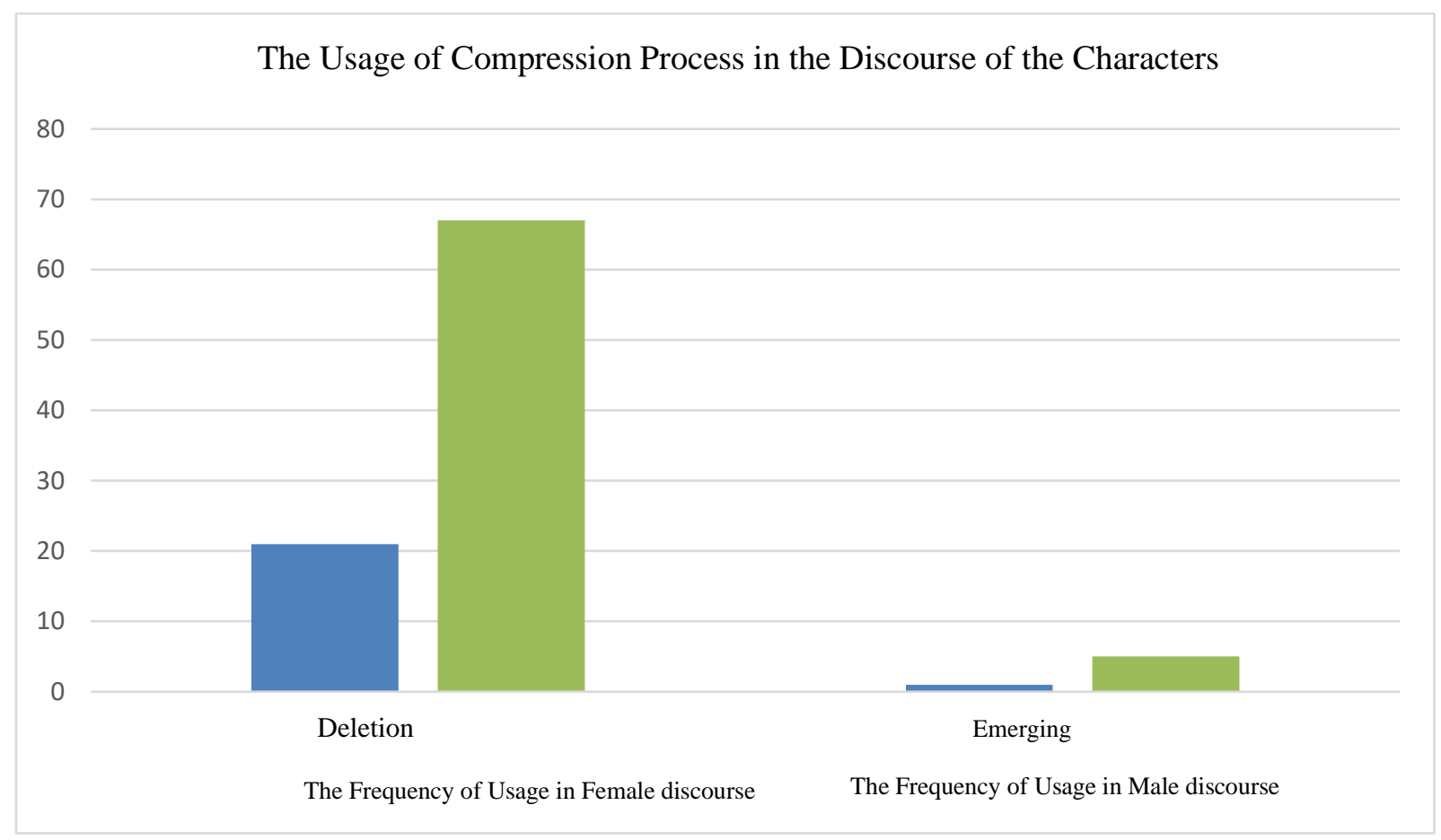

Graph (1) The Usage of Compression Process in the Discourse of the Characters of the "Kaiser" Film

Compression in the Discourse of the Female and Male Characters of "Treasure of the Qaroon" Film

\section{The Process of Compression in Female Characters}

\section{Deletion in Nouns:}

1- [naneye 2ali: 2âxe mixâstam pirhanamo tamum konam]

2- [naneye 2ali: Zali zenqad az to nefrat dâre ke hâzer is ye deyqe ham to run eye to zendegi kone]

1- $\quad$ Ali's Mom: I just wanted to finish your dress.

2- $\quad$ Ali's Mom: Ali hates you so much that doesn't wana live in your house even a second.

\section{Deletion of Verbs:}

1- [xânume zarparast: faqat heyf ke širin zuno duseš nadâre]

2- [širin: čete 2ali]

1- Mrs. Zarparast: It's a pity that Shirin doesn't like him.

2- $\quad$ Shirin: What's up, Ali?!

\section{Deletion in Adverbs:}

1- [širin: čeqad to 2âdam razli hasti 2ali]

2- [zinat: četo momkene man be 2un goftam to mordi] 
1- Shirin: What a bastard you are, Ali.

2- Zinat: How is it possible? I told her you are dead.

\section{Deletion in Nouns:}

1- [širin: behešam $2 a z$ šomâ goftam]

2- [zane zarparast: 2az mâm čizi beheš gofti]

1- Shirin: I told him about you.

3- $\quad$ Mrs. Zarparast: Did you tell her anything about us.

Table (4-6) The Usage of Deletion Process in the Discourse of the Female and Male Characters of "Treasure of the Qaroon" Film

\begin{tabular}{|l|l|l|}
\hline & Deletion Process & The Frequency of Usage in Discourse \\
\hline 1 & Deletion of Nouns & 4 \\
\hline 2 & Deletion in Verbs & 3 \\
\hline 3 & Deletion in Adjectives & 0 \\
\hline 4 & Deletion in adverbs & 3 \\
\hline 5 & Deletion in letters & 4 \\
\hline
\end{tabular}

The Process of Merging

\section{Merging in Letters:}

1- [zane zarparast: $\underline{\text { 2angoštaro bebinam] }}$

1- Mrs. Zarparast: Let me see the ring.

Table (4-7) The Usage of Merging Process in the Discourse of the Female and Male Characters of "Treasure of the Qaroon" Film

\begin{tabular}{|l|l|l|}
\hline & Merging Process & The Frequency of Usage in Discourse \\
\hline 1 & Merging in Nouns & 0 \\
\hline 2 & Merging in verbs & 0 \\
\hline 3 & Merging in adjectives & 0 \\
\hline 4 & Merging in Adverbs & 0 \\
\hline 5 & Merging in Letters & 1 \\
\hline
\end{tabular}

Compression in the Discourse of the Male Characters of "Treasure of the Qaroon" Film

The Process of Deletion

\section{Deletion in Nouns}

1- [xedmatkâr: bebaxšid 2âqâye qârun kolâhetuno lotfan] 
2- [qârun: mamad 2ali to ke sâlhâs piše man xedmat mikoni]

1- $\quad$ Servant: Pardon me, Mr. Qarun! Hand in your hat, please.

2- $\quad$ Qarun: Mamad Ali, you worked for me many years.

\section{Deletion in Verbs:}

1- [2ali: mese 2inke hâleš xub ni]

2- [2ali: Zage mardi bâ man dar biof]

1- Ali: It seems that he is not all right.

2- $\quad$ Ali: If you are a man, grapple with me.

\section{Deletion in Adjectives:}

1- [2ali: bolan šo biyâ boxor]

2- [2ali: dâšte 2az gošnegi xodešo mikošte]

1- Ali: Come over to eat.

2- $\quad$ Ali: He was about to kill himself of hunger.

\section{Deletion in Adverbs:}

1- [2ali: bogu 2âbji 2enqad lefteš nade]

2- [qârun: בenqad be man xedmat mikoni bâyad mano xub bešnasi]

1- $\quad$ Ali: tell the sis not to delay.

2- Qarun: You serve me so much, you should know me well.

\section{Deletion in Nouns:}

1- [xedmatkâr: nabâyad xodetuno nârâhat konin]

2- [zarparast: tarif kon bebinam kârâ dar če hâle]

1- Servant: You shouldn't make yourself so worried.

2- Zarparast: Tell me to see. How is everything going?

Table (4-8) The Usage of Deletion Process in the Discourse of the Male Characters of "Treasure of the Qaroon" Film

\begin{tabular}{|l|l|l|}
\hline & Deletion Process & The Frequency of Usage in Discourse \\
\hline 1 & Deletion of Nouns & 36 \\
\hline 2 & Deletion in Verbs & 69 \\
\hline
\end{tabular}




\begin{tabular}{|l|l|l|}
\hline 3 & Deletion in Adjectives & 11 \\
\hline 4 & Deletion in adverbs & 25 \\
\hline 5 & Deletion in letters & 40 \\
\hline
\end{tabular}

The Process of Merging

\section{Merging in Nouns:}

1- [xedmatkâr: xodetuno nârâhat nakonin qorbân]

2- [2ali: čerâ xodeto 2enghad 2azâb midi]

1- Servant: Master, don't make yourself so worried.

2- $\quad$ Ali: Why you bother so much.

Table (4-9) The Usage of Merging Process in the Discourse of the Male Characters of "Treasure of the Qaroon" Film

\begin{tabular}{|l|l|l|}
\hline & Merging Process & The Frequency of Usage in Discourse \\
\hline 1 & Merging in Nouns & 2 \\
\hline 2 & Merging in verbs & 0 \\
\hline 3 & Merging in adjectives & 0 \\
\hline 4 & Merging in Adverbs & 0 \\
\hline 5 & Merging in Letters & 0 \\
\hline
\end{tabular}

Table (4-10) The Usage Compression Process in the Discourse of the Characters of "Treasure of the Qaroon" Film

\begin{tabular}{|l|l|l|l|}
\hline & Compression & $\begin{array}{l}\text { The Frequency of Usage in Female } \\
\text { discourse }\end{array}$ & The Frequency of Usage in Male discourse \\
\hline 1 & Deletion & 14 & 181 \\
\hline 2 & Merging & 1 & 2 \\
\hline
\end{tabular}




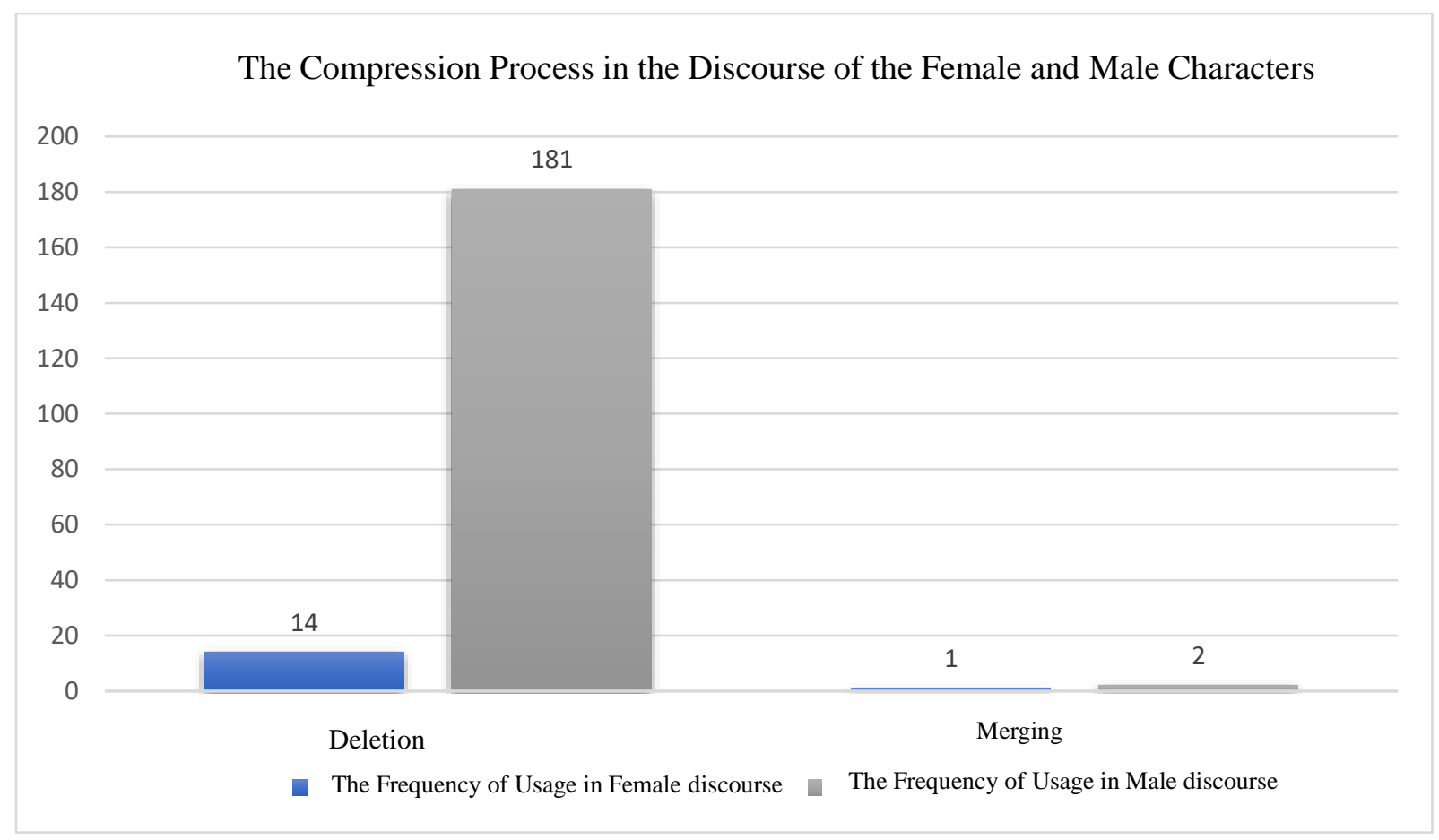

Graph (2) The Usage of Compression Process in the Discourse of the Characters of "Treasure of the Qaroon" Film

\section{The New Cinematic Films}

"Lottery," a film whose director is Mohammad Hossein Mahdavian, written by Ibrahim Amini and Mohammad Hossein Mahdavian is produced by Seied Mahmood Razavi in 2017. The typical genre of this film is societalromantic (dramatic-romantic), and it has a bitter epical atmosphere. Life+1 Day" is a film directed and written by Saied Rosstaie, and it is produced by Saied Malekan in 2014. This film has social (dramatic) genre.

\section{The compression in the Discourse of the Male and Female characters of "Lottery"}

\section{The compression in the Discourse of the Female characters of "Lottery"}

\section{Deletion Process}

\section{Deletion in Nouns:}

1. [nušin: hâlâ 2in hame râ 2umadi 2inâ ro begi]

2. [nasrin: tu 2in 2ozâ Zahvâl bâyad havâseš be xodeš bâše dige]

1- Noushin: Now, you have come so far to say these.

2- Nasrin: In such a situation, he should take care of himself.

\section{Deletion in Verbs:}

1. [nušin: hamin 2alân berim dige]

2. [nušin: Zâre kojâs bodo dire]

1- Noushin: Let's go right now. 
3- Noushin: Ya, where is it? Run. It's late.

\section{Deletion in Adverbs:}

1. [nušin: čerâ zenqad zang mizani]

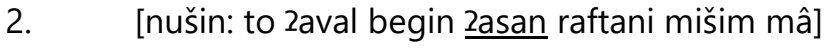

1- Noushin: Why do you call so much?

2- Noushin: First, see if we are really about to go.

\section{Deletion in Letters:}

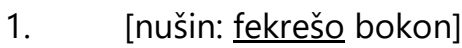

2. [nušin: bâdigârdât râho barât vâ mikonan]

1- Noushin: Just think about it.

1- $\quad$ Noushin: Your bodyguards pave the way for you.

Table (4-7) The Usage of Deletion Process in the Discourse of the Female Characters of the "lottery" Film

\begin{tabular}{|l|l|l|}
\hline & Merging Process & Frequency of Usage in Discourse \\
\hline 1 & Merging in Nouns & 13 \\
\hline 2 & Merging in verbs & 17 \\
\hline 3 & Merging in adjectives & 0 \\
\hline 4 & Merging in Adverbs & 7 \\
\hline 5 & Merging in Letters & 12 \\
\hline
\end{tabular}

\section{Merging Process}

There was found no evidence of any kind of merging in "Lottery"

\section{Compression in the Discourse of Male Characters in the "Lottery" film.}

\section{Deletion Process}

\section{Deletion in Nouns:}

1- [sâmân: dasšui nemiri]

2- [2amir 2ali: mamud zâqâ betun gift 2âre]

1- Saman: Don't you wanna go to the bath?

2- $\quad$ Amir Ali: Did Mr. Mamood tell you? Ya! 


\section{Deletion in Verbs:}

1- [pedare nušin: 2ino begin binam]

2- [musâ: mixâi sibilâmo bezanam]

1- Noushin's Father: Get it.

1- Moses: Do you like me to shave my moustache?!

\section{Deletion in Adjectives:}

1- [bâbâye nušin: harfe lâddamizâ hâlit nemiše]

2- [2amir 2ali: 2âhâ yani či yani haminjur dasxâli bargardim hiči be hiči]

1- Noushin's Father: Don't you understand my words?

2- $\quad$ Amir Ali: Aha! What does you mean? You mean to get back empty-handed like this, All for nothing?

\section{Deletion in Adverbs:}

1- [musâ: mage nemigam sef bâzi nakon]

2- [bâbâye Zamir Zali: Zun Zaz pedareš ke dasforuše o ravâniye]

2- Moses: Ain't I telling you not to play so rough?!

3- $\quad$ Amir Ali's Father: His father, who is a packman and psycho.

\section{Deletion in Letters:}

1- [naim: hâlâ bad az tamâm šodane 2in kârâ harkodum zazin šeixa yeki dotâ zazin doxtarâ ro zentexâb mikonan]

2- [2amir 2ali: bede man ček konam] (bede be a man: 'be' is completely deleted)

1- Naiem: Now, after everything is over, each one of these Sheikhs pick one of these girls.

2- Amir Ali: Let me check it out.

Table (4-12) The Usage of Deletion Process in the Discourse of the Female Characters of the "Lottery" Film

\begin{tabular}{|l|l|l|}
\hline & Deletion Process & Frequency of Usage in Discourse \\
\hline 1 & Deletion of Nouns & 56 \\
\hline 2 & Deletion in Verbs & 96 \\
\hline 3 & Deletion in Adjectives & 34 \\
\hline 4 & Deletion in adverbs & 22 \\
\hline 5 & Deletion in letters & 75 \\
\hline
\end{tabular}




\section{Merging Process}

\section{Merging in Nouns:}

1- [2amir 2ali:

2- [2amir 2ali: 2az madresaš motenafere]

1- Amir Ali: Thanks.

2- $\quad$ Amir Ali: He hates his school.

Merging in adjectives:

1- [2amir Zali: gošname bâbâ či šod]

1- Amir Ali: I'm hungry. What happened?

Table (4-13) The Usage of Merging Process in the Discourse of the Female Characters of the "Lottery" Film

\begin{tabular}{|l|l|l|}
\hline & Merging Process & Frequency of Usage in Discourse \\
\hline 1 & Merging of Nouns & 4 \\
\hline 2 & Merging in Verbs & 0 \\
\hline 3 & Merging in Adjectives & 1 \\
\hline 4 & Merging in adverbs & 0 \\
\hline 5 & Merging in letters & 0 \\
\hline
\end{tabular}

Table (4-14) The Usage of Compression Process in the Discourse of the Characters of the "Lottery" Film

\begin{tabular}{|l|l|l|l|}
\hline & Compression & $\begin{array}{l}\text { The Frequency of Usage in } \\
\text { Female discourse }\end{array}$ & $\begin{array}{l}\text { The Frequency of Usage in Male } \\
\text { discourse }\end{array}$ \\
\hline 1 & Deletion & 46 & 283 \\
\hline 2 & Merging & 0 & 5 \\
\hline
\end{tabular}


The Compression Process in the Discourse of the Male and Female Characters

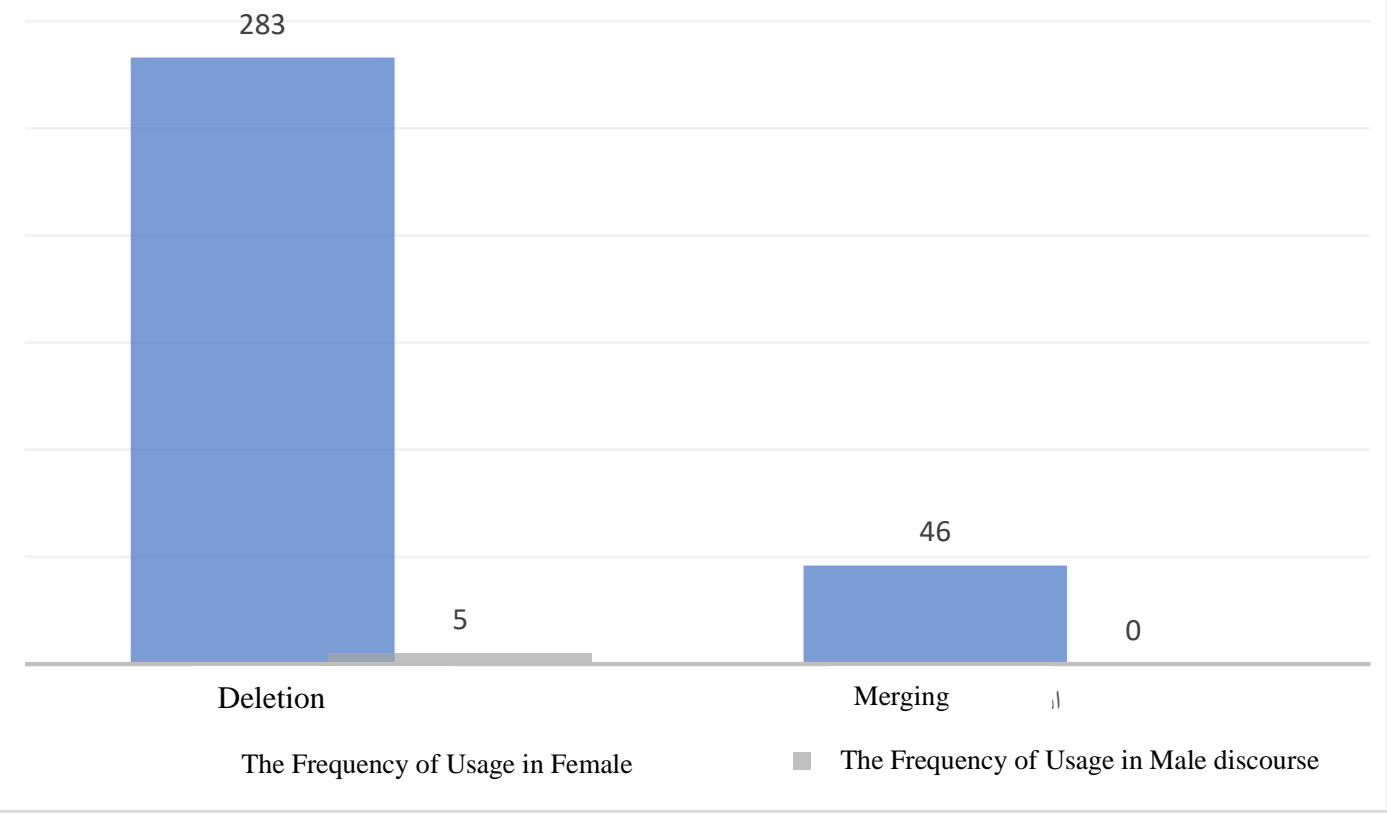

Compression in the Discourse of the Male and Female Characters of the "Life+1 Day" Film

Compression in the Discourse of the Female Characters of the "Life+1 Day" Film

The Process of Deletion

\section{Deletion in Nouns:}

1- [2azam: sabtenâm kardam devisšiš]

2- [leilâ: das bezanam tamâme badanam kahir mizane]

1- $\quad$ Azam: I signed up, 206.

2- $\quad$ Leila: With the slightest touch, I get rashes.

\section{Deletion in Verbs:}

1- [somaye: vâ mikone mixore mige 2in ye tikaš sâleme]

2- [mâdar: man mixâm 2ino qâbeš konam bezanam be divâr]

1- $\quad$ Somaie: He opens and eats it, and he says this part is ok.

2- $\quad$ Mother: I want to put it on a frame and hang it on the wall.

\section{Deletion in Adjective:}

1- [somaye: navid leilâram bidâr mikardi nayâd nesfe šabi zâberâmun kone bâz]

2- [mâdar: qazâye manam das naxordas]

1- Somaie: Navid, you should have woken up Leila so that she wouldn't bother us at midnight again. 
2- Mother: My food is also untouched.

\section{Deletion in Verbs:}

1- [somaye: diruzam ke 2asan naraf]

2- [leilâ: xo 2a kojâ mazlum dobâre nayân]

1- Somaie: Yesterday, he didn't go at all.

2- Leila: Ha, who can tell they won't come back again.

\section{Deletion in Letters:}

1- [somi: leilâram bidâr mikardi biyâd šâmešo boxore]

2- [2azam: some mâm 2unjâ kasi ro nadâre]

2- $\quad$ Somy: You should have woken up Leila so that she could have her dinner.

3- $\quad$ Azam: Our Somaie has no one there too.

Table (4-15) The Usage of Deletion Process in the Discourse of the Female Characters of the "Life+1 Day" Film

\begin{tabular}{|l|l|l|}
\hline & Deletion Process & Frequency of Usage in Discourse \\
\hline 1 & Deletion in Nouns & 66 \\
\hline 2 & Deletion in Verbs & 88 \\
\hline 3 & Deletion in Adjectives & 22 \\
\hline 4 & Deletion in adverbs & 15 \\
\hline 5 & Deletion in letters & 81 \\
\hline
\end{tabular}

\section{Merging Process}

\section{Merging Nouns:}

1- [2azam: somaye daset dard nakone]

2- [mâdar: man ye jâ qâyam karde budam ke 2aqle jenam nemiresid]

1- Azam: Somaie, thanks.

2- $\quad$ Mother: I hid it somewhere that nobody would have ever guessed.

\section{Merging in adjectives:}

1- [somaye: miše čantâšo bardâram] 
1- Somaie: Can I take a few?

\section{Merging in Verbs:}

1- [somaye: base dige]

2- [šahnâz: $\underline{\text { base dige] }}$

1- Somaie: Enough is enough.

2- Shahnaz: Enough!

\section{Merging in Nouns:}

1- [2azam: dast 2asareš bardâr]

2- [mâdar: doxtaram Začâle nayofti tu čâ]

1- Azam: Leave her alone, Leila.

2- $\quad$ Mother: My dear, take care not to be out of the frying pan into the fire.

Table (4-16) The Usage of Merging Process in the Discourse of the Female Characters of the "Life+1 Day" Film

\begin{tabular}{|l|l|l|}
\hline & Merging Process & Frequency of Usage in Discourse \\
\hline 1 & Merging in Nouns & 5 \\
\hline 2 & Merging in Verbs & 3 \\
\hline 3 & Merging in Adjectives & 1 \\
\hline 4 & Merging in adverbs & 0 \\
\hline 5 & Merging in letters & 3 \\
\hline
\end{tabular}

\section{Compression in the Discourse of the Male and Female Characters of the "Life +1 Day" Film}

\section{Deletion Process}

\section{Deletion in Nouns:}

1- [mortezâ: mâm Zalân Zasire dâdgâ pâsgâ budim]

2- [moZalem: toluxâni zin seri bargardam bargato pâre mikonamâ]

1- $\quad$ Morteza: We also were caught busy in Police Station and Court.

2- Teacher: Tolouekhani! If I turn back next time, I'll rip your paper. 


\section{Deletion in verbs:}

1- [mortezâ: Zamir va kon binam kari]

2- [mohsen: na bâbâ čizi nis]

1- Morteza: Amir, open up, are you deaf!

2- Mohsen: Never mind, it's nothing.

\section{Deletion in Adjectives:}

1- [mohsen: berim xodemunno nešun bedim yevax fek nakonan balaxa nadari]

2- [mohsen: das xâli budi jološun 2injit kardan]

1- $\quad$ Mohsen: Let's show up, less they think you haven't got any fans.

2- Mohsen: You were empty-handed that's why they treated you as such.

\section{Deletion in Adverbs:}

1- [mortezâ: somaye mâ 2inâro čejuri tamiz konim]

2- $\quad$ [mohsen: 2in ke 2asan xodetam nemiduni kiye]

1- Morteza: Somaie, how do we clean these?

2- $\quad$ Mohsen: You don't even know that guy.

\section{Deletion in letters:}

1- [2amir: šomâre refiqâye mano mixâi čikâr]

2- [mozalem: 2in seri bargato migiramâ]]

1- $\quad$ Amir: Why do you need my buddies' numbers.

2- $\quad$ Teacher: Next time, I'll take your paper.

Table (4-17) The Usage of Deletion Process in the Discourse of the Male Characters of the "Life+1 Day" Film

\begin{tabular}{|l|l|l|}
\hline & Deletion Process & Frequency of Usage in Discourse \\
\hline 1 & Deletion in Nouns & 100 \\
\hline 2 & Deletion in Verbs & 103 \\
\hline 3 & Deletion in Adjectives & 31 \\
\hline 4 & Deletion in adverbs & 16 \\
\hline 5 & Deletion in letters & 89 \\
\hline
\end{tabular}




\section{Merging Process}

\section{Merging in Nouns:}

1- [morteza: 2in daseš beškane badbaxtiš vâseye kiye]

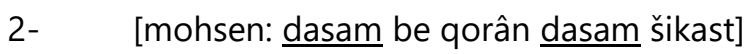

1- Morteza: If his hand is broken, who is going to take care of him.

2- Mohsen: My hand, I swear to God my hand is broken.

\section{Merging in Verbs:}

1- [navid: rafiqeš har šab miyâd dombâleš]

2- [morteza: somaye base dige]

1- Navid: His buddies come to pick him up every night.

3- Morteza: Somaie, enough is enough.

\section{Merging in Adverbs:}

1- [mortezâ: har čeqad migi batar mikone]

2- [navid: batar šod ke]

1- $\quad$ Morteza: The more you say, he makes it worse.

2- Navid: It got worse.

\section{Merging in Letters:}

1- [Mohsen: 2in bače 2aman be pedar mâdareš či mige]

2- [mohsen: ֵi mixâd xuna ro xâli kone barâ xodeš]

1- Mohsen: What is this kid telling about me to his parents.

2- Mohsen: He is evacuating the house for himself.

table (4-18) The Usage of Merging Process in the Discourse of the Male Characters of the "Life+1 Day" Film

\begin{tabular}{|l|l|l|}
\hline & Merging Process & Frequency of Usage in Discourse \\
\hline 1 & Merging in Nouns & 8 \\
\hline 2 & Merging in Verbs & 5 \\
\hline 3 & Merging in Adjectives & 0 \\
\hline 4 & Merging in adverbs & 3 \\
\hline 5 & Merging in letters & 5 \\
\hline
\end{tabular}


Table (4-19) The Usage of Compression Process in the Discourse of the Characters of the "Life+1 Day" Film

\begin{tabular}{|l|l|l|l|}
\hline & Compression & $\begin{array}{l}\text { The Frequency of Usage in } \\
\text { Female discourse }\end{array}$ & $\begin{array}{l}\text { The Frequency of Usage in Male } \\
\text { discourse }\end{array}$ \\
\hline 1 & Deletion & 727 & 339 \\
\hline 2 & Merging & 12 & 21 \\
\hline
\end{tabular}

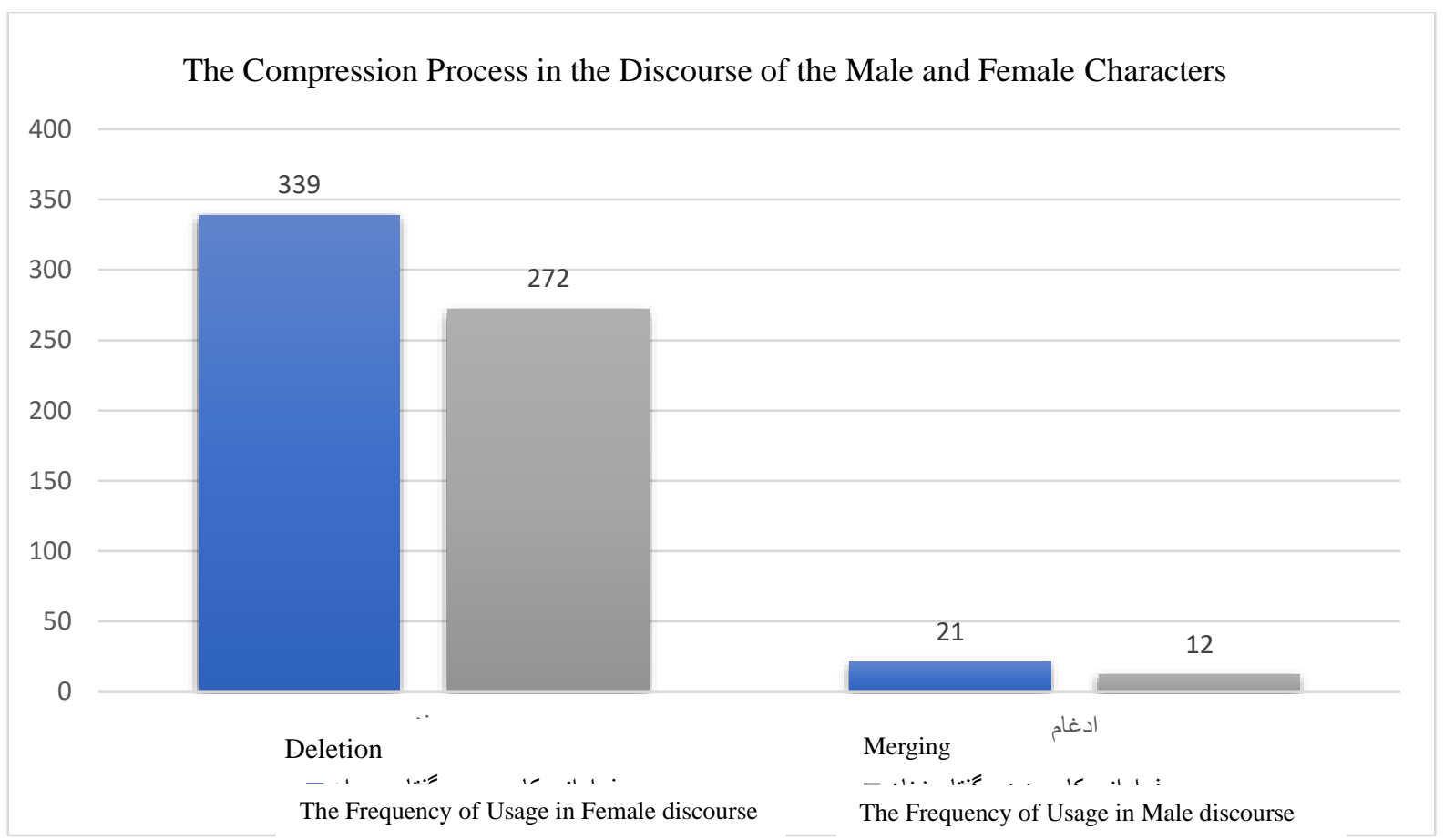

\section{Graph (4) The Usage of Compression Process in the Discourse of the Characters of the "Life+1 Day"} Film

\section{5- Conclusion}

After analyzing the data in the two old films and the two new ones mentioned, the compression process in the old films was 292 cases (283 deletions, 9 mergers) and in the new films 978 cases (940 deletions, 38 merging). It has also been shown that the compression process is more evident in men than in women's discourse. According to data survey, men had the lowest compression rate 360 cases (339 deletions, 21 merges) and in women 284 cases ( 272 deletions, 12 mergers), compared to men have the lowest compression rate and the compression process is more pronounced in verbs than in other lexical items. As in the "Life+1 Day" film: 799 cases of compressed verbs, the "lottery movie": 113 cases, "Treasure of the Qaroon"! 72, and the "Kaiser" ; 30 cases, and a total of 1014 compression in verbs occurred that has the highest rate comparing to adjectives, nouns, adverbs, and letters. These can be named as the best findings of this study that elucidate the reasons for the phonological distinction of compression.

In terms of cognitive and social usage, women are more meticulous in their speech in terms of linguistic standards than men. Therefore, they are more careful about their speech in social relations. And on the other hand, as a linguistic educator and the educational role that women play in their children, they try to use 
phonological words correctly, which might be a reason for their less tendency to compression and less usage of deletion and merging processes.

The issue of verb category has the most phonological expression due to its features of modality, grammatical aspect, and time that these roles are compensated by other elements at the sentence level. The grammaticalization process of the vocabulary and the subsequent compression process diachronically have proved that Old Persian interactions with the new Persian conversation through grammaticalization and compression create phonological changes in higher frequency cases and samples. Therefore, at some point in compression, the most phonological changes can be seen. Such as deleting / $t$ / in "S" instead of "is" or in "dahanesho bas" insteat of " bast "and deleting / d / in /mikonan/ which is necessarily accompanied by deleting and merging in Persian of the homophones of / D / and / $t /$ which is one of the most common cases of compression of verbs in Persian and it can be said to have the most deletion.

This is apparently due to the negligence of the speaker in the dialogue or homophony, but what can be described from the Bybee usage-based phonological perspective, the frequency of some of the verbs in the dialogue, and consequently the common points in the listeners' mental backgrounds that trigger the intensive process of compression and reduction are the minimum phonological repreentation required in the dialog. In the grammaticalization process, compression can also be cognitively justified, meaning that the auxiliary verbs and adverbs mediate the subdivision steps through the grammaticalization to go to clitic processes derivatives and even to the path of deletion and merging. Given the frequency of their usage in interactions, they are most likely to be deleted and merged, which also confirms our biased phonological theory and our hypothesis in this study in the Persian language.

The fact that the two categories of nouns and verbs are part of the basic entity of a phrase, such that if these categories are frequent, are compressed or eliminated. On the other hand, the presence of an adjective, adverb or prepositional phoneme to describe and even as replacement of the noun or verb in the conceptual connection with the listener's mind is sufficient to represent them, and this is in agreement with Bybee's view point. So the compression, deleting, or merging processes in them has happened less frequently.

This is a confirmation of Bybee's idea (2001) that the most frequent word causes the most phonetic change, that in this research, the verbs in the language are the most frequent because the verbs have the most compression, especially in the linking verbs with the highest frequency. So, according to the research carried out in the Persian language, it proceeds in the same direction, the results of this study indicate that the creation of new meaning and concept is in verb. If the frequency of an element is high, it costs less, and vice versa, if the frequency of an element is low, it means that the mind has to work harder to maintain it. Language always tends to eliminate elements whose cost is high, and their efficiency is low, and on the contrary, in order to express their meaning they use the less expensive elements; that is, they use the components that already exist in the language, and they have a high frequency. Frequent words can be independent of other vocabulary generalizations, as is the verb generative in this study is more frequent.

\section{References:}

1. Alderete, J. \& Tupper, P. (2018). Connectionist approaches to generative phonology. The Routledge handbook of phonological theory.

2. Bybee, B. (2010). Language, Usage, and Cognition. Cambridge: Cambridge University Press.

3. Bybee, B. (2004). Phonology and Language Use (third ed.). Cambridge: Cambridge University Press.

4. Bybee, B. \& Hopper, P. (2001). Introduction to frequency and Emergence of Linguistic Structure (pp.126). Amesterdam-Philadelphia: John Benjamin B.V.

5. Bybee, B. (1999). Usage-based phonology (pp.211-242). The University of New Mexico. 
6. Evans, V., \& Green, M. (2006). Cognitive linguistics: An introduction. Edinburgh: Edinburg University Press Ltd.

7. Field, J. (2004). Psycholinguistics: The key concepts. London: Routledge.

8. Fowler, C. A. \& Housum J. (1987). Talkers' signaling of "new" and "old" words in speech and listeners' perception and use of the distinction. Journal of Memory and Language, 26, 489--504.

9. Hayes, B. (1989). Introductory Phonology. Blackwell Publishing.

10. Hicky, R. (2014). Phonological change in English. The Cambridge Handbook of English Historical Linguistics Cambridge: Cambridge University Press.

11. Kahn, D. (1976). Syllable-based generalizations in English phonology. Ph.D. thesis, MIT. Published by Garland, New York, 1980.

12. Kambuziya, A. (2018). Phonology: Rule-Based Approaches \& their Applications in Persian. Samt publishing.

13. Kristiansen, G. (2003). How to Do Things with Allophones. In R.F.Rene Dirven, Cognitive Model in Language and Thought, Ideology, Metapher, and Meaning (pp. 69-120). Berlin: Mouton Degruyter.

14. Kristiansen, G.( 2006). Towards a usage-based cognitive phonology. International Journal of English studies, 6 (2), 107-140.

15. Kwon, H. (2017). Language experience, speech perception, and loanword adaption: variable adaption of English word-final plosive into Korean (pp. 1-19). Elsevier.

16. Lahiri, A, Wilson, M., (1991). Form a phonological approach to the recognition lexicon. NCBI.

17. Lackoff, G. (1989). Cognitive Phonology. The Berkeley Conference on Nonderivational Phonology. Berkeley: University of California at Berkeley.

18. Langacker, R. (2008). Cognitive grammar: A basic introduction. Oxford: Oxford University Press.

19. Langacker, R. (1999). Assessing the cognitive linguistics enterprise. In T.Janssen, \& G.Redeker, Cognitive Linguistics: Foundations, Scope, and Methodology (pp. 13-60). Berline: Mouton De Gruyter.

20. Langacker, R. (1988). A usage-based model. Topics in cognitive linguistics (Current Issues in Linguistic Theory) (pp. 61-127). Amesterdam: John Benjamins.

21. Lee, D. (2001). Cognitive linguistics: An introduction. South Melbourne: Oxford University Press.

22. Mikaiili, F., Farahani, M.N. (2005). Studying Phonological Processing Model for Students Normal and Dyslexic Boy of Primary School. Research on Exceptional Children, Winter 2006, Vol.18, No. 4,379-416.

23. Moeng, E., Boehm, J., Reynolds, A. (2015). Modeling the interlanguage: The effect of frequency in the L2 acquisition of English consonant clusters. Studies in the Linguistic Sciences.

24. Mücke, D., Hermes, A., Cho, T. (2017). Mechanisim of regulation in speech: Linguistic structure and physical control system.

25. Munson, B. (2010). Level of phonological abstraction and socially motivated speech-sound variation. (pp. 157-177). The University of Minnesota. 
26. Nathan, G.S. (1996). Step towards cognitive phonology. In B. Hurch, \& R. A. Rhodes, Natural phonology: The State of Art (pp. 107-120). Berlin: Mouton De Greuyter.

27. Occhino, C. (2016). A cognitive approach to phonology-evidence from signed and spoken languages. Rochester Institue of Technology-Center Cognition and Language.

28. Redford, M., Oh, G. (2017). The representation and execution of articulatory timing in first and second language acquisition. Elsevier.

29. Richtsmeier, P., Goffman, L. (2017). Perceptual statistical learning over one week in child speech Production (pp. 70-80). Elsevier.

30. Rosen, R. (2004). Beginning L2 production errors in ASL lexical phonology- A cognitive phonology (pp. 31-61). John Benjamins Publishing Company.

31. Safaie-Qalati, Mehdi. (2013). A Study of Compensatory Lengthening in Persian through a Usage-based Cognitive Approach: Exploring the Possibility of a Mono-stratal Model of Phonology (Ph.D.'s thesis). Tarbiat Modares University, Tehran, Iran.

32. Skipper, J., Devlin, J., Lametti, D. (2017). The hearing ear is always found close to the speaking tongue: Review of the role of the motor system in speech perception (pp. 77-105). Elsevier.

33. Stillings, N.A., Weisler, S.E., Chase, C.H., Feinstein, M.H., Garfield, J.L., \& Rissland E.L. (1995). Cognitive science: An introduction (2nd ed.). Cambridge, MA: MIT Press.

34. Taylor, J.R. (2002). Cognitive Grammar. Oxford: Oxford University Press.

35. Thayer Jensen, J. (2004). Principles of Generative Phonology: An Introduction(pp.217-251). John Benjamins Publishing.

36. Treiman, R. (2017). Learning to spell-phonology and beyond. Cognitive neuropsychology Washington University.

37. Yang, J., Fox, R. (2017). L1-L2 interactions of vowel systems in young bilingual Mandarin-English children. Elsevier. 